\title{
EVALUATION OF ANTICANCER ACTIVITY OF PARKINSONIA ACULEATA LEAVES EXTRACT ON EHRLICH'S ASCITES CARCINOMA-INDUCED MICE
}

\author{
PRAMEELA RANI A, NAGARJUNA BABU E*, PREM MADHUR S, RAVI CHANDRA SEKHARA REDDY D, \\ PHANI KUMAR K
}

Department of Pharmacology, University College of Pharmaceutical Sciences, Acharya Nagarjuna University, Nagarjuna Nagar, Guntur, Andhra Pradesh, India. Email: etukurinagarjuna@gmail.com

Received: 05 September 2017, Revised and Accepted: 26 October 2017

ABSTRACT

Objective: The objective of the study was to investigate the anticancer activity of the ethanolic extract of Parkinsonia aculeata (EEPA) leaves.

Methods: Anticancer activity of $P$. aculeata (EEPA) of leaf extract was evaluated in Swiss albino mice against Ehrlich ascites carcinoma (EAC) cell line at the doses of 200 and $400 \mathrm{mg} / \mathrm{kg}$ body weight orally. The extracts were administered for 14 consecutive days. $24 \mathrm{~h}$ of the last dose and $18 \mathrm{~h}$ of fasting, the mice were sacrificed, and the anticancer effect of EEPA was assessed by evaluating tumor volume, viable and nonviable tumor cell count, tumor weight, hematological parameters, and biochemical parameters of EAC bearing mice.

Results: P. aculeata extracts showed a significant decrease in $(\mathrm{p}<0.01)$ tumor volume, viable cell count, tumor weight, and elevated the life span of EAC bearing mice. Hematological profile such as red blood cell, hemoglobin count reverted to normal level in EEPA treated mice. The extracts significantly $(\mathrm{p}<0.05)$ decreased the levels of lipid peroxidation and significantly $(\mathrm{p}<0.05)$ increased the levels of reduced glutathione, superoxide dismutase and catalase.

Conclusion: The results showed that the EEPA was effective in inhibiting the tumor growth in ascitic models and that is comparable to 5-fluorouracil.

Key words: Ehrlich ascites carcinoma induced model, Anticancer, Parkinsonia aculeata, 5-fluorouracil.

(C) 2018 The Authors. Published by Innovare Academic Sciences Pvt Ltd. This is an open access article under the CC BY license (http://creativecommons. org/licenses/by/4. 0/) DOI: http://dx.doi.org/10.22159/ajpcr.2018.v11i1.22404

\section{INTRODUCTION}

Cancer is the term which indicates the uncontrollable programmed growth of the abnormal cell in the body. It can occur in any part of the body which disturbs the normal mechanism of a working cell. There are different types of cancers which are the leading cause of death in worldwide [1]. More than $70 \%$ of cancer deaths occur in low- and middle-income countries. More than 30\% of cancers are due to behavioral and environmental changes. Tobacco is the biggest cause of cancer, which is responsible for up to 1.5 million cancer deaths a year. There are many treatments for cancer such as surgery, chemotherapy, and radiation therapy. Existing chemotherapy and treatment leads to different painful side effects. Hence, there is a need for implementation of new alternative and complementary medicine with anticancer activity. Plants are the source of enormous potential to provide the latest drugs which are the reservoir of natural chemicals that may provide chemoprotective potential against cancer [2]. Parkinsonia aculeata is a large shrub found in the parts of America, Mexico, and some regions of India. It is commonly known as "Jerusalem thorn" [3]. Plant-derived natural products such as glycosides, flavonoids, reducing sugars, and sterols are present in the P. aculeata possessing the desired pharmacological effects [4]. P. aculeata L. possess various pharmacological activities, antibacterial, antidiabetic, antioxidant, amoebicidal, hepatoprotective, antispermatogenic activity, and antimalarial activity [5,6]. Previous investigations showed that the leaves of this plant contain orientation, ISO-orientin, vitexin, isovitexin, lucenin-II, vicenin-II, diosmetin 6-C-Bglucoside, apigenin, luteolin, kaempferol, chrysoeriol, apparently, parkinsonin-A, parkinsonin-B, and parkintin $[7,8]$. Studies of in vitro and in vivo have shown that some flavonoids modulate the metabolism and disposition of carcinogens and can contribute to cancer prevention $[9,10]$.

\section{METHODS}

\section{Plant Collection}

The fresh leaves were collected from the fields of Siripuram Village, Guntur District, Andhra Pradesh, India. The plant was authenticated as P. aculeata (Family: Fabaceae) by Prof. P. Satyanarayana Raju, Department of Botany, Acharya Nagarjuna University, Guntur, Andhra Pradesh. It was shade dried at room temperature and then made into coarse powder. The powdered plant material was extracted by ethanol using Soxhlet extraction apparatus, and the solvent is completely removed under reduced pressure by rotavapor apparatus. Ethanolic extract of $P$. aculeata (EEPA) was used in the entire study.

\section{Animals}

Healthy Male Swiss albino mice weighing between 20 and 25 GM was used for the study. A total of 60 animals was maintained in polyacrylic cages with Standard Laboratory Conditions (temperature $25 \pm 2{ }^{\circ} \mathrm{C}$ and relative humidity under a $12 \mathrm{~h}$ light/dark cycle) and fed with standard pellet diet and water ad libitum. The mice were acclimatized to laboratory conditions a weakness before the work. The protocol was approved by the IAEC of Acharya Nagarjuna University College of Pharmaceutical Sciences.

\section{Transplantation of tumor cells}

Ehrlich ascites carcinoma (EAC) cells were procured from Amala Cancer Research Centre, Thrissur and Kerala, India. The cell line was maintained in vivo in Swiss albino mice [9]. The ascetic fluid was drawn out from the EAC tumor-bearing mouse at log phase (7-8 days of tumor-bearing) of tumor cells using an 18-gauge needle into a test tube and then it was washed using a phosphate buffer solution (PBS) up to 3 times to remove the other tissues which may have been collected along with the fluid. The ascetic fluid was centrifuged at 1500 RPM for about $5 \mathrm{~min}$, and then a pale pink colored pellet was formed at the bottom of 
the test tube. The supernatant fluid was discarded, and the pellet was washed thoroughly with PBS. Then, it was diluted with PBS, and the stock sample solution was prepared and subjected to the Trypan blue viability test to determine the number of viable cells present in $1 \mathrm{ml}$ of the stock suspension using hemocytometer. Since the stock suspension, $1 \times 10^{6}$ cells $/ 0.1 \mathrm{ml}$ was prepared with $\mathrm{PBS}$, and each mice were injected with $0.1 \mathrm{ml}$ of the fluid suspension intraperitoneally to obtain Ehrlich ascetic tumor [11].

\section{Viable cell count}

The sample solution was prepared by adding the $0.4 \%$ Trypan blue to the cell suspension and left aside for 3-5 min at room temperature to ensure proper staining. The sample solution was taken in a hemocytometer, cells were counted under the microscope in four $1 \mathrm{~mm} \times 1 \mathrm{~mm}$ squares of one chamber and were determined the average number of cells per square. The number of unstained cells represents the number of viable cells in the suspension. The total number of viable cells was counted.

\section{Acute toxicity study}

From the previous literature, it was proved that the oral administration of $2000 \mathrm{mg} / \mathrm{kg}$ was not shown mortality in animals. The extract was found safe in animals dosed at $2000 \mathrm{mg} / \mathrm{kg}$ [9].

\section{In vivo study}

The female Swiss albino mice weighing about 20-25 g were divided into five groups consisting of 12 each. Animals were fasted overnight before the start of the experimental procedure. Except, Group I all groups were being injected with EAC cells $\left(1 \times 10^{6}\right.$ cells $\left./ 0.1 \mathrm{ml} \mathrm{IP}\right)$ this was marked as a day "0." Group I was served as normal saline control and Group II was served as EAC control given with normal saline (10 ml $/ \mathrm{kg}$, i.p). Groups III, $\mathrm{IV}$, and V were being administered with 5-fluorouracil (5-FU) $(20 \mathrm{mg} / \mathrm{kg}$ i.p.), EEPA (200 mg and $400 \mathrm{mg} / \mathrm{k.g}$ b.w p.o), respectively, once daily for 14 consecutive days. After administrations of the past dose, 6 mice from each group were kept fasting for $18 \mathrm{~h}$ and blood was collected by retro-orbital method under mild ether for the estimation of hematological parameters. Moreover, the ascitic fluid was aspirated from the peritoneal cavity for the estimation of tumor growth responses such as tumor volume and viability. From each group of the animal's liver is isolated for the purpose of histopathological studies. Rest of animals in each group were kept alive with food and water ad libitum to determine the mean survival time (MST) and percentage increase life span (ILS) of the host animal.

\section{Tumor volume and weight}

The mice were dissected, and the ascitic fluid was drawn from the peritoneal cavity, and the volume of the fluid was measured by taking it into the graduated centrifuge tube and expressed in milliliters $(\mathrm{ml})$. The weight of the tumor was measured by taking the mice before and after collection of the ascitic fluid from the peritoneal cavity and expressed in $\operatorname{gram}(\mathrm{g})$.

\section{Tumor cell count (viable/nonviable)}

The ascitic fluid was taken in a pipette and diluted up to 20 times with PBS solution. Then a drop of the diluted cell suspension was placed in the Neubauer's counting chamber, and the number of cells in the 64 small squares was counted.

The cells were stained with Trypan blue $(0.4 \%$ in normal saline) dye. The cells that did not take up the dye were viable, and those that took the stain were nonviable. These viable and nonviable cells were counted using the formula:

$$
\text { Cell count }=\frac{(\text { No. of cells } \times \text { Dilution factor })}{(\text { Area } \times \text { Thickness of liquid film })}
$$

\section{Hematological and biochemical parameters}

The blood collected from the experimented animals was used for the estimation of hemoglobin (Hb), red blood cell (RBC), and white blood cell (WBC) count by standard procedures [12] and biochemical parameters such as lipid peroxidation (LPO), reduced glutathione (GSH), superoxide dismutase (SOD), and catalase (CAT) [13].

\section{Percentage ILS}

ILS was calculated by estimating the effect of EEPA on tumor growth by recording the mortality of the mice used for the experiment.

Mean survival time (MST) in days = (day of first death + day of last death)/2

ILS $(\%)=($ MST of the treated group $/$ MST of the control group $)-1 \times 100$

\section{Histopathological studies}

A portion of the liver in animals of each group was stored in a container for $12 \mathrm{~h}$ in $10 \%$ formalin solution and subjected to histopathological studies. This was followed by dehydration with isopropyl alcohol of increasing strength $(70 \%, 80 \%$, and $90 \%)$ for $12 \mathrm{~h}$ each. Then, the final dehydration is done using absolute alcohol with about their changes for $12 \mathrm{~h}$ each. The liver sample was embedded in paraffin blocks and sectioned into $5 \mu \mathrm{m}$ size. The slides were stained with eosin and hematoxylin.

\section{Statistical analysis}

All the experimental data are expressed as the mean \pm standard error of the mean. The data were statistically analyzed using one-way analysis of variance followed by Dunnett's post hoc test using GraphPad Prism 5.0.

\section{RESULTS}

Effect of EEPA extract on change in the tumor growth (Table 1)

The reliable criteria for judging the value of any anticancer drug are the prolongation of life span of the animals and the decrease of leukemic cells from blood [10]. However, with the treatment of EEPA the percent increase in tumor cell volume and a number of viable tumor cells were found to be significantly less when compared to the EAC control. Hence, it may be concluded that the extracts by a direct cytotoxic effect and by arresting the tumor growth, ILS of EAC-bearing mice. The percentage ILS at the $400 \mathrm{mg} / \mathrm{kg}$ body weight dose of the leaf extract was found to be higher.

Effect of EEPA on hematological and biochemical parameters (Table 2)

A significant change was observed in both haematological and biochemical parameters and are expressed in the tabular form. These changes between them are compared with each group for the effect of EEPA.

\section{Effect of EEPA on hematological parameters}

A significant reduction in RBC was observed in EAC induced control $(2.12 \pm 0.09)$ when compared to normal $(7.03 \pm 0.17)$. Treatment with standard drug 5 -FU $20 \mathrm{mg} / \mathrm{kg}$ has significantly reversed the decrease of RBC to normal (5.11 \pm 0.04 ). Both doses $200 \mathrm{mg}$ and $400 \mathrm{mg}$ of EEPA show the significant increase in the RBC compared with normal.

A significant increase in WBC was observed in EAC induced control $(14.0 \pm 0.27)$ when compared to the normal $(6.12 \pm 0.27)$. Treatment with standard drug 5 -FU $20 \mathrm{mg} / \mathrm{kg}$ has significantly reversed the increase in WBC and change observed is near to the normal $(6.64 \pm 0.10)$. Both doses of EEPA showed the reversal of increased WBC compared to the control.

The percentage of the $\mathrm{Hb}$ was decreased in the EAC inoculated mice $(14.2 \pm 0.05)$ in comparisons with a normal animal (14.2 \pm 0.05$)$ standard treatment with $5 \mathrm{FU} 20 \mathrm{mg} / \mathrm{kg}$ has significantly reversed the decreased $\mathrm{Hb}$ percentage $(13.1 \pm 0.08)$ when compared the normal. Treatment with EEPA significantly increases the level of HB to the normal.

\section{Effect of EEPA on biochemical parameters}

Significant decrease in the levels of LPO, GSH, SOD, and CAT was observed in the EAC control group which was significantly reversed to its normal 
Table 1: Effect of EEPA extract on change in the tumor growth

\begin{tabular}{lllll}
\hline Parameters & EAC control & $\mathbf{5 - F U}$ & $\mathbf{2 0 0} \mathbf{~ m g} / \mathbf{k g}$ & $\mathbf{4 0 0} \mathbf{~ m g} / \mathbf{k g}$ \\
\hline Tumor volume $(\mathrm{ml})$ & $3.92 \pm 0.10$ & $1.15 \pm 0.11$ & $2.72 \pm 0.03$ & $1.92 \pm 0.05$ \\
Tumor weight $(\mathrm{g})$ & $4.54 \pm 0.05$ & $1.21 \pm 0.02$ & $2.71 \pm 0.04$ & $1.95 \pm 0.04$ \\
MST (days) & 22.5 & 43 & 28 & 36.5 \\
\% ILS & - & 91.1 & 24.4 & 62.2 \\
Viable tumor cell $\left(\times 10^{7}\right.$ cells $\left./ \mathrm{ml}\right)$ & $9.83 \pm 0.52$ & $2.52 \pm 0.16$ & $4.83 \pm 0.15$ & $3.96 \pm 0.08$ \\
Nonviable tumor cell $\left(\times 10^{7}\right.$ cells $\left./ \mathrm{ml}\right)$ & $0.8 \pm 0.13$ & $2.91 \pm 0.04$ & $1.3 \pm 0.51$ & $0.98 \pm 0.16$ \\
\hline
\end{tabular}

All values are expressed as mean \pm SEM for six animals in each group. All values are found out using one-way ANNOVA followed by Dennett's post-hoc test of significance. EEPA: Ethanolic extract of Parkinsonia aculeate, EAC: Ehrlich ascites carcinoma, ILS: Increase life span, MST: Mean survival time, SEM: Standard error of the mean, ANNOVA: Analysis of variance

Table 2: Effect of EEPA on hematological and biochemical parameters

\begin{tabular}{lllll}
\hline Treatment & Normal & EAC & 5-FU & 200 mg/kg \\
\hline Hb $\%$ & $14.2 \pm 0.05$ & $7.03 \pm 0.17$ & $13.1 \pm 0.08$ & $9.45 \pm 0.18$ \\
RBC $\left(10^{6} / \mathrm{mm}^{3}\right)$ & $5.48 \pm 0.03$ & $2.12 \pm 0.09$ & $5.1 \pm 0.04$ & $3.48 \pm 0.09$ \\
WBC $\left(10^{3} / \mathrm{mm}^{3}\right)$ & $6.12 \pm 0.27$ & $14.0 \pm 0.27$ & $6.64 \pm 0.10$ & $9.79 \pm 0.05$ \\
LPO (nmol MDA/mg protein) & $1.06 \pm 0.70$ & $1.50 \pm 0.40$ & $1.08 \pm 0.70$ & $1.36 \pm 0.02$ \\
GSH (mg/g) & $2.56 \pm 0.04$ & $1.58 \pm 0.41$ & $2.50 \pm 0.61$ & $7.17 \pm 0.04$ \\
SOD (U/mg protein) & $4.83 \pm 0.04$ & $2.62 \pm 0.08$ & $4.77 \pm 0.13$ & $1.18 \pm 0.90$ \\
CAT (U/mg protein) & $26.4 \pm 0.12$ & $10.8 \pm 0.86$ & $25.5 \pm 0.23$ & $3.71 \pm 0.07$ \\
\hline
\end{tabular}

All values are expressed as mean \pm SEM for six animals in each group. All values are found out using one-way ANNOVA followed by Dunnett's post hoc test of significance. EEPA: Ethanolic extract of Parkinsonia aculeate, EAC: Ehrlich ascites carcinoma, SEM: Standard error of the mean, ANNOVA: Analysis of variance, Hb: Hemoglobin, RBC: Red blood cell, WBC: White blood cell, LPO: Lipid peroxidation, GSH: Reduced glutathione, SOD: Superoxide dismutase, CAT: Catalase, MDA: Malondialdehyde

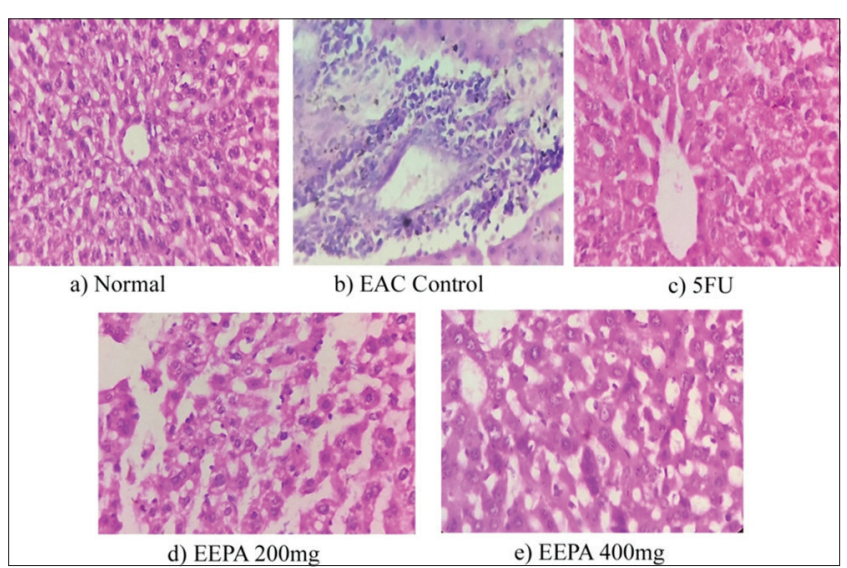

Fig. 1: Histopathological changes in liver

values in the EEPA treated group. Almost similar results were observed with 5-FU treatment. It was observed that tumor cells produced more peroxides when they proliferate actively after inoculation of tumor and also known to affect many functions of the vital organs, which indicated the intensification of oxygen free radical production. The elevation of lipid peroxidation is also known to be associated with cancer. Decrease in SOD, GSH, and CAT activities described in tumors is regarded as markers of malignant transformation. Therefore, the significant elevation $(\mathrm{p}<0.05)$ of GSH, SOD, and CAT, and significantly $(p<0.05)$ reduction in LPO of the extract treatment confirm the potent antioxidant activity and free radical quenching property of EEPA.

\section{Effect of EEPA on histopathological studies}

The histopathological observation of liver sections of normal, EAC tumor control, standard drug 5-FU, and EEPA extract treated animals collected at the end of the experimental periods, i.e., Day 14. Normal untreated animals showed normal lobular architecture with intact central vein and sinusoids, normal portal tracts and preserved hepatocytes. EAC induced animals showed necrosis, surrounding fibrosis, perivenular inflammation, and vacuole formation. However, mice treated with EEPA plant extract showed reduced vacuole formation, and inflammation and almost normal hepatocellular architecture were observed (Fig. 1).
Histopathological examination showed a protective effect of EEPA on hepatotoxicity.

\section{DISCUSSION}

The Ehrlich tumor cells are one of the rapidly growing carcinoma with very aggressive behavior and are able to grow in almost all strains of mice [14]. The present study was conducted to evaluate the anticancer activity of P. aculeata on EAC bearing mice. Plants are the major source of the medicinal uses which can help in the treatment of various incurable diseases. Plant materials consist of the several natural products which are extracted by different techniques. Parkinson equality is the medicinal shrub which consists of flavonoids and glycosides. Flavonoids like quercetin, orientation have been shown to possess antimutagenic and anti-malignant effect [15]. Ethanol is used for the extraction of the P. aculeata for obtaining effective results.

Treatment with EEPA of low-dose and high-dose showed the significant ILS and nonviable cell count and reduced the tumor volume, tumor weight and viable tumor cell count when compared to the control group EAC (Table 1). Hematological parameters such as $\mathrm{Hb}$ content and RBC count decreased, and total WBC count increased significantly in EAC group when compared to the normal group. The RBC count and $\mathrm{Hb}$ content increased, while the WBC decreased in comparison with EAC control [16].

The suitable criteria for estimation of an anticancer drug are based on the widening the life span of the animals and the decrease effected cells from blood [17]. While treating with EEPA, the percent increase in tumor growth was found to enhance with cancer control. Hence, it indicated a potent anticancer nature by a significant change in life span at $400 \mathrm{mg} / \mathrm{kg}$. Major conditions occur in cancer chemotherapy are myelosuppression and anemia [18]. Anemia occurred in ascites carcinoma is due to iron deficiency, either by a hemolytic or myelopathy condition which finally leads to a decrease of RBC count [19].

Plant-derived extracts containing antioxidant principles showed cytotoxicity toward tumor cells and antitumor activity in experimental animals. The lowering of LPO and increase in levels of GSH, SOD, and CAT in EEPA treated group indicates its potential as an inhibitor of EAC induced mice $[20,21]$. 
In addition, treatment with EEPA showed a significant inhibition of metastasis in the liver, indicating their antimetastatic activity which is also supported by its antitumor and hepatoprotective activities. Thus, the additive and synergistic antioxidant activity of phytochemicals such as flavonoids present in $P$. aculeata could be responsible for its potent antitumor activity.

\section{CONCLUSION}

On the basis of the above results, it is concluded that the EEPA possesses significant anticancer activity. The activity may be due to the presence of one or more phytochemical constituents present in the extract. Further studies warranted, for isolation of the constituents responsible for the activity and also to explore the exact mechanism of action of the activity.

\section{ACKNOWLEDGMENT}

The authors are very much thankful for Principal, University College of Pharmaceutical Sciences, Acharya Nagarjuna University, Guntur, Andhra Pradesh, for encouragement and support.

\section{REFERENCES}

1. Gennari C, Castoldi D, Sharon O. Natural products with taxol-like antitumor activity: Synthetic approaches to eleutherobin and dictyostatin. Pure Appl Chem 2007;79:173-80.

2. Khlifi S, EI Hachimi Y, Khalil Y, Khalil Y, Khalil A, ES-Safi N, et al. In vitro antioxidant properties of Salvia verbenaca $\mathrm{L}$. hydromethanolic extract. Indian J Pharmacol 2006;38:276-80.

3. Albrecht J, editor. Tree Seed Handbook of Kenya. Nairobi, Kenya: GTZ Forestry Seed Center Muguga; 1993.

4. Singh P, Shrivastava R, Saxena R, Sharma M, Karchuli M, Tripathi J. Phytochemical screening and evaluation of antioxidant activity of Parkinsonia aculeate L. (Family-Leguminoseae) leaves extract. IJPRIF 2011;3:1952-17.

5. Kamal R, Mathur N. Rotenoids from Parkinsonia aculeata $\mathrm{L}$ and their in vitro. amoebicidal activity. Asian J Exp Sci 2007;21:317-23.

6. Patel P, Jivani NP, Malaviya SV, Bhalodia Y. Phytochemical study and antiparkinson's activity of Parkinsonia aculeata and Ananas comosus L. effect on haloperidol induced catalepsy. Ethnopharmacology 2014;2014:17.

7. Gupta MK, Kenganora M, Banerjee A, Saini L, Kuma V. Pharmacognostical and phytochemical evaluation on the bark of
Parkinsonia aculeata Linn. J Pharm Sci Biosci Res 2011;1:86-92.

8. Divya B, Mruthunjaya K, Manjula SN. Parkinsonia aculeata: Phytopharmacological review. Asian J 2008;4:1-7.

9. Priyam S, Rajni S, Manik S, Manvendra S. In vivo antitumor, antioxidant activities and toxicity profile of ethyl acetate crude leaf extract of Parkinsonia equality on B16F10 Melanoma. Int Res J Pharma 2013;4:89.

10. Gupta M, Mazumder UK, Kumar RS, Sivakumar T, Vamsi ML. Antitumor activity and antioxidant status of Caesalpinia bonducella against ehrlich ascites carcinoma in Swiss albino mice. J Pharmacol Sci 2004;94:177-84.

11. Aishwarya V, Abdulla SS, Dheeba B, Renuka R. In vitro antioxidant and anticancer activity of Cardiospermum halicacabum L. against EAC cell line. Int J Pharm Pharm Sci 2014;6:263-8.

12. Ahuja R, Agrawal N, Mukerjee A. Evaluation of the anticancer potential of Terminalia chebula fruits against ehrlich ascites carcinoma induced cancer in mice. J Sci Innov Res 2013;2:549-54.

13. Muralidhar A, Somasekhar A, Sumanjali A, Kumar BP. Anticancer activity of Tephrosia purpurea root extracts against ehrlich ascites carcinoma (EAC) cells in Swiss albino mice. Pharm Sin 2014;5:81-7.

14. Segura JA, Barero LG, Marquez J. Elrich ascites tumor unbalanced splenic cell population and reduced responsiveness of $\mathrm{T}$ cell to Staphylococcus. Immunomol Lett 2000;74:111-15.

15. Harborne JB, Williams CA. Advances in flavonoid research since 1992. Phytochemistry 2000;55:481-4

16. D'Armour FE, Blood FR, Belden DA. The Manual for Laboratory Work in Mammalian Physiology. $3^{\text {rd }}$ ed. Chicago: The University of Chicago; 1965

17. Bala A, Kar B, Haldar PK, Mazumder UK, Bera S. Evaluation of anticancer activity of Cleome gynandra on ehrlich's ascites carcinoma treated mice. J Etna Pharmacol 2010;129:131-4.

18. Sreelatha S, Padma PR, Umasankari E. Evaluation of anticancer activity of ethanol extract of Sesbania grandiflora (Agati sesban) against ehrlich ascites carcinoma in Swiss albino mice. J Ethnopharmacol 2011;134:984-7.

19. Gupta M, Mazumder UK, Rath N, Mukhopadhyay DK. Antitumor activity of methanolic extract of Cassia fistula L. Seed against ehrlich ascites carcinoma. J Ethnopharmacol 2000;72:151-6.

20. Naveena, Bharath BK, Selvasubramanian. Antitumor activity of Aloe vera against ehrlich ascitis carcinoma (Eac) in Swiss albino mice. Int $\mathrm{J}$ Pharm Bio Sci 2011;2:400-9.

21. Arora S, Agarwal S, Singhal S. Anticancer activities of thiosemicarbazides/thiosemicarbazones: A review. Int J Pharm Pharm Sci 2014;6:1179-85 